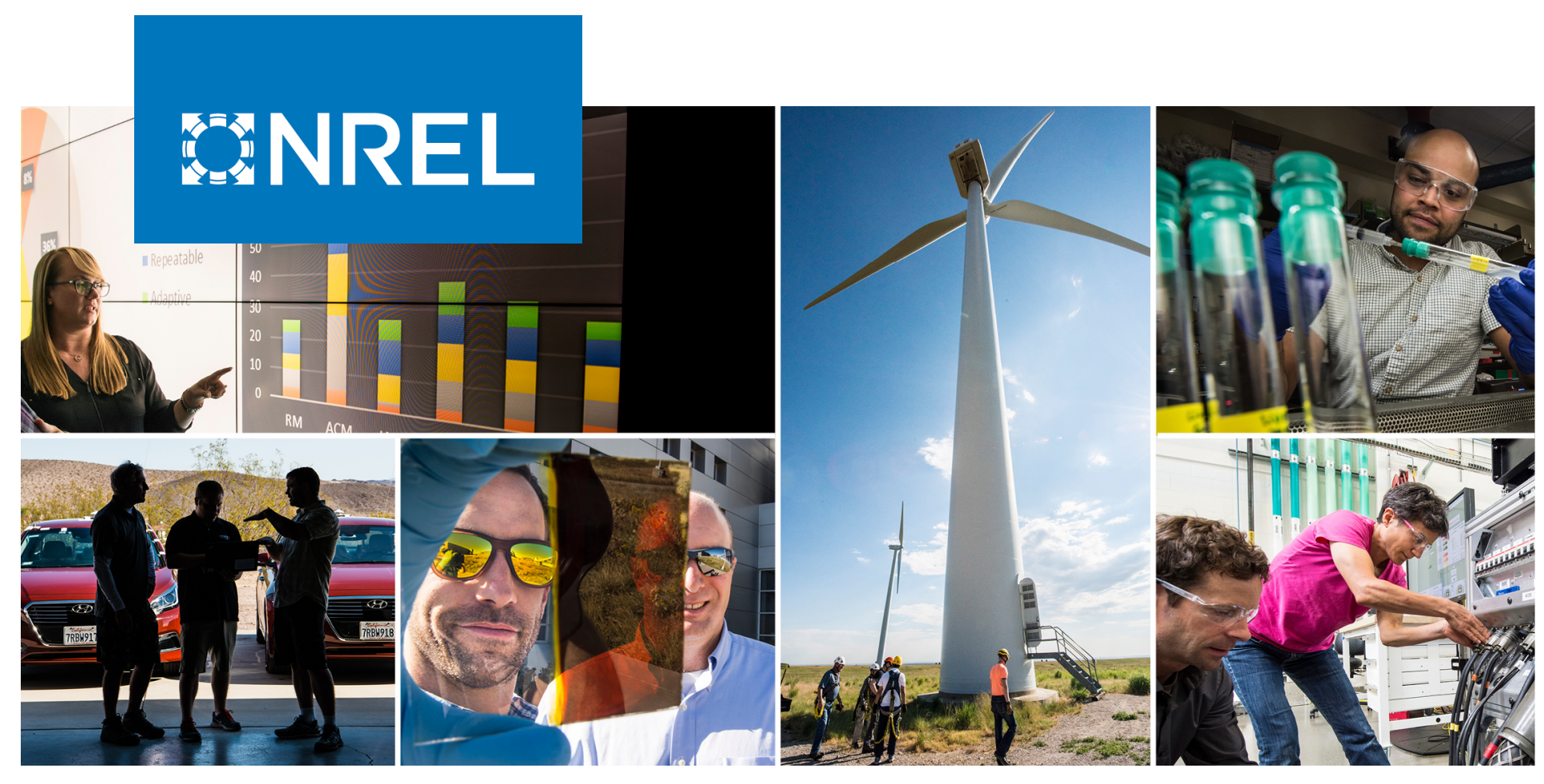

\title{
U.S. Airport Infrastructure and Sustainable Aviation Fuel
}

Kristi Moriarty and Allison Kvien

National Renewable Energy Laboratory

NREL is a national laboratory of the U.S. Department of Energy

Office of Energy Efficiency \& Renewable Energy

Operated by the Alliance for Sustainable Energy, LLC

This report is available at no cost from the National Renewable Energy Laboratory (NREL) at www.nrel.gov/publications.
Technical Report

NREL/TP-5400-78368

February 2021 


\title{
GNREL
}

\section{U.S. Airport Infrastructure and Sustainable Aviation Fuel}

\author{
Kristi Moriarty and Allison Kvien
}

National Renewable Energy Laboratory

\section{Suggested Citation}

Moriarty, Kristi, and Allison Kvien. 2021. U.S. Airport Infrastructure and Sustainable Aviation Fuel. Golden, CO: National Renewable Energy Laboratory.

NREL/TP-5400-78368. https://www.nrel.gov/docs/fy21osti/78368.pdf.

NREL is a national laboratory of the U.S. Department of Energy Office of Energy Efficiency \& Renewable Energy Operated by the Alliance for Sustainable Energy, LLC

This report is available at no cost from the National Renewable Energy Laboratory (NREL) at www.nrel.gov/publications.

Contract No. DE-AC36-08GO28308
Technical Report

NREL/TP-5400-78368

February 2021

National Renewable Energy Laboratory 15013 Denver West Parkway Golden, CO 80401

303-275-3000 • www.nrel.gov 


\section{NOTICE}

This work was authored by the National Renewable Energy Laboratory, operated by Alliance for Sustainable Energy, LLC, for the U.S. Department of Energy (DOE) under Contract No. DE-AC3608GO28308. Funding provided by U.S. Department of Energy Office of Energy Efficiency and Renewable Energy Bioenergy Technologies Office. The views expressed herein do not necessarily represent the views of the DOE or the U.S. Government.

This report is available at no cost from the National

Renewable Energy Laboratory (NREL) at

www.nrel.gov/publications.

U.S. Department of Energy (DOE) reports produced

after 1991 and a growing number of pre-1991

documents are available

free via www.OSTI.gov.

Cover Photos by Dennis Schroeder: (clockwise, left to right) NREL 51934, NREL 45897, NREL 42160, NREL 45891, NREL 48097, NREL 46526.

NREL prints on paper that contains recycled content. 


\section{Acknowledgments}

This work was funded by Department of Energy's Bioenergy Technologies Office. The National Renewable Energy Laboratory appreciates Airports Council International's data gathering and reviews as well as input from the Federal Aviation Administration, and reviews from the aviation industry. 


\section{List of Acronyms}

ACI

AHS

AST

COA

CORSIA

EIA

EPA

FAA

FCT

FT

HEFA

IATA

ICAO

OEM

PADD

RCQ

RIN

RFS

SAF

SKA

SPCC

SPK

UST
Airports Council International

airport fuel hydrant system

aboveground storage tank

Certificate of Analysis

Carbon Offsetting and Reduction Scheme for International Aviation

U.S. Energy Information Administration

U.S. Environmental Protection Agency

Federal Aviation Administration

field-constructed tank

Fischer-Tropsch

hydrogenated esters and fatty acids

International Air Transport Association

International Civil Aviation Organization

original equipment manufacturer

Petroleum Administration for Defense District

Refinery Certificate of Quality

Renewable Identification Number

Renewable Fuel Standard

sustainable aviation fuel

synthetic kerosene with aromatics

Spill Prevention, Control, and Countermeasure

synthetic paraffinic kerosene

underground storage tank 


\section{Executive Summary}

Worldwide, aviation accounts for $2 \%$ of all human-caused carbon dioxide $\left(\mathrm{CO}_{2}\right)$ emissions and $12 \%$ of all transportation $\mathrm{CO}_{2}$ emissions (ATAG 2019). In 2018, the United States accounted for $25 \%$ of the world jet fuel consumption and $21 \%$ of global enplanements (an instance of a person boarding a plane) (EIA 2020a; FAA 2020; ATAG 2019). Airports and airlines are considering alternative fuel to meet environmental and sustainability goals and mandates. Sustainable aviation fuel (SAF), made from non-petroleum feedstocks, has the potential to significantly reduce emissions from air transportation. SAF must be blended with petroleum-based jet fuel prior to its use in aircraft. SAF is defined as an advanced biofuel under the Renewable Fuel Standard (RFS). ${ }^{1}$ This report explores background information on jet fuel use, quality standards and practices, airport infrastructure, and options for delivering SAF to airports.

In 2016, the International Civil Aviation Organization (ICAO), a branch of the United Nations, adopted the Carbon Offsetting and Reduction Scheme for International Aviation (CORSIA) to cap net $\mathrm{CO}_{2}$ aviation emissions at 2020 levels through 2035. Industry have also set aspirational goals of reducing $\mathrm{CO}_{2}$ emissions by 50\% compared to 2005 levels by 2050 .

SAF production is in its early stages, with one domestic commercial plant and at least two under construction in 2020; Neste is also producing in Europe and exporting to the United States. There are pilot and demonstration-scale plants in the United States and throughout the world. Public data for the RFS indicate a domestic market of over 4.5 million gallons in 2020 (EPA 2020b). As of late 2020, SAF is blended with petroleum jet fuel and delivered via truck to Los Angeles International Airport and via pipeline to San Francisco International Airport. There is an expectation that initially, SAF will be utilized in California due to pricing advantages from credits generated under the Low Carbon Fuel Standard (LCFS).

Jet fuel quality standards and certification documents are essential to fuel safety. Jet A fuel meets ASTM D1655 Standard Specification for Aviation Turbine Fuels. ${ }^{2}$ ASTM D7566 Standard Specification for Aviation Turbine Fuel Containing Synthesized Hydrocarbons is the specification SAF must meet prior to blending with Jet A. Refineries co-processing a biomass or intermediate renewable feedstock with crude oil at a refinery would meet ASTM D1655. SAF produced at a stand-alone facility would meet ASTM D7566. ${ }^{3}$ When Jet A and SAF are blended and tested for compliance with all applicable ASTM standards, the fuel is then designated as ASTM D1655, allowing it to be transported in pipelines and used in aircraft.

Each batch of jet fuel produced at a refinery generates a batch number and undergoes a full conformity test to generate a Refinery Certificate of Quality (RCQ). A Certificate of Analysis (COA) is generated for each batch of jet fuel as it moves through the supply chain requiring retesting of key fuel properties. SAF should generate a similar quality documentation at the point of production. A COA would be generated at the point where Jet A and SAF are blended.

\footnotetext{
${ }^{1} \mathrm{SAF}$ in this report refers to the neat fuel - the blending component that must be blended with Jet A prior to use in aircraft.

${ }^{2}$ Standards are continuously updated. Check the ASTM website for the latest version.

https://www.astm.org/Standards/D1655.htm

${ }^{3}$ https://www.astm.org/Standards/D7566.htm
} 
The method of moving fuels throughout the country depends on the location of production, fuel type, and volume. The modes of transport for fuels include barge/ship, pipeline, rail, and truck. Jet A moves primarily by pipeline, whereas biofuels produced at stand-alone facilities are moved by rail (large volumes), barge, or truck (small volumes). If SAF is co-processed with conventional Jet A at an existing refinery, an RCQ would be generated and the fuel would flow through the supply chain in a business-as-usual model via pipeline directly to an airport or, more commonly, by pipeline to a terminal and then by pipeline to an airport

The initial small volumes of SAF production may result in some unique blending situations and blended fuel may be delivered to an airport by truck where possible. This report focuses on blending options for SAF at anticipated higher volumes. The requirements of quality control point toward blending of SAF from a stand-alone facility with Jet A at a terminal. One option to ensure quality and allow for total control of percent volume of SAF is to store SAF and Jet A separately and blend them at the desired ratio into a third tank (Figure ES-1). Fuel sampling and testing of fuel in the third tank would allow for generating the required documentation for fuel quality and ensuring all applicable ASTM standards are met. Another option would be to store SAF and Jet A together in the same tank at the terminal (Figure ES-2). Minor challenges with this method include detailed inventory tracking as tanks are constantly receiving and dispensing fuel as well as the potential need to add mixing equipment to account for variability in density between the two fuels. Option 2 may be the best option for the initial small volumes of SAF expected for both economic and fuel storage purposes. Both options could also be used to blend fuel for delivery by truck to airports not connected to pipelines.

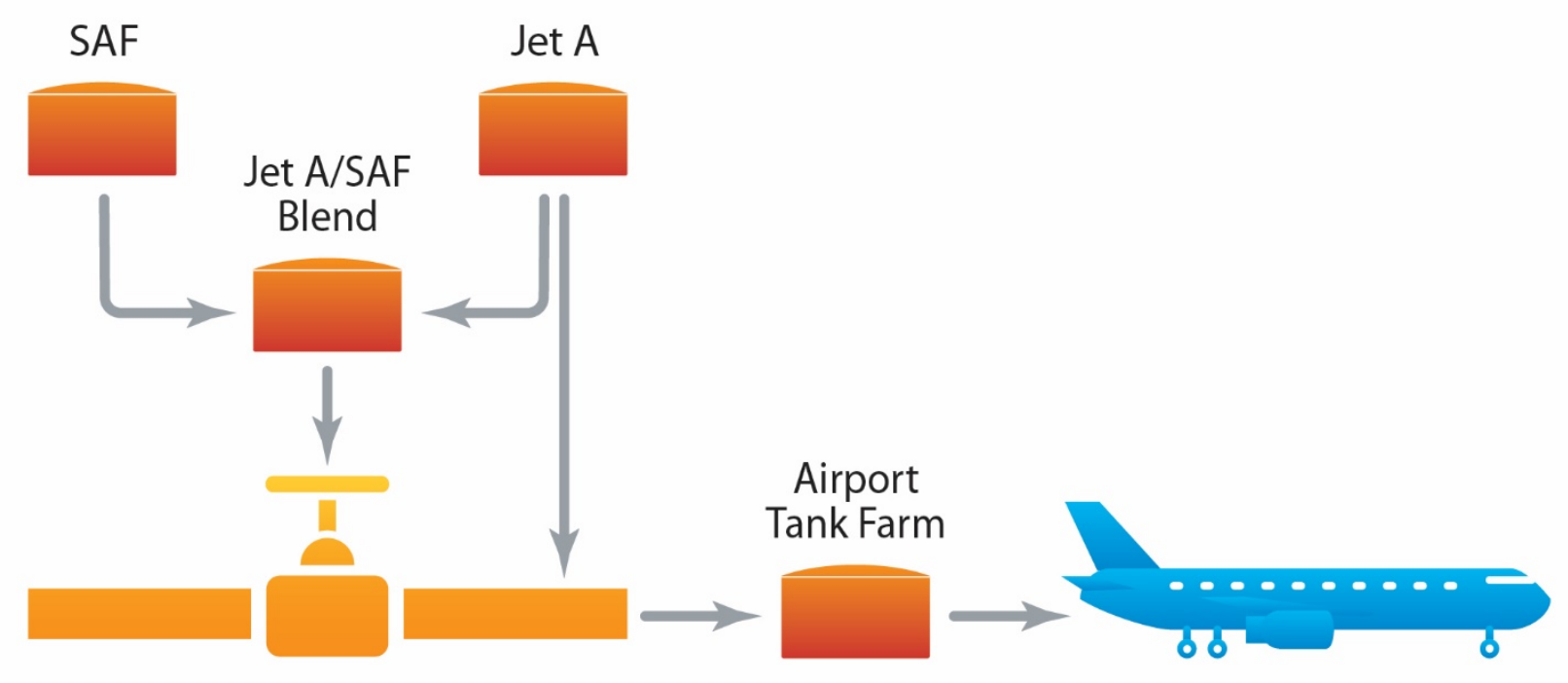

Figure ES-1. Option 1 for blending Jet A and SAF at a terminal 


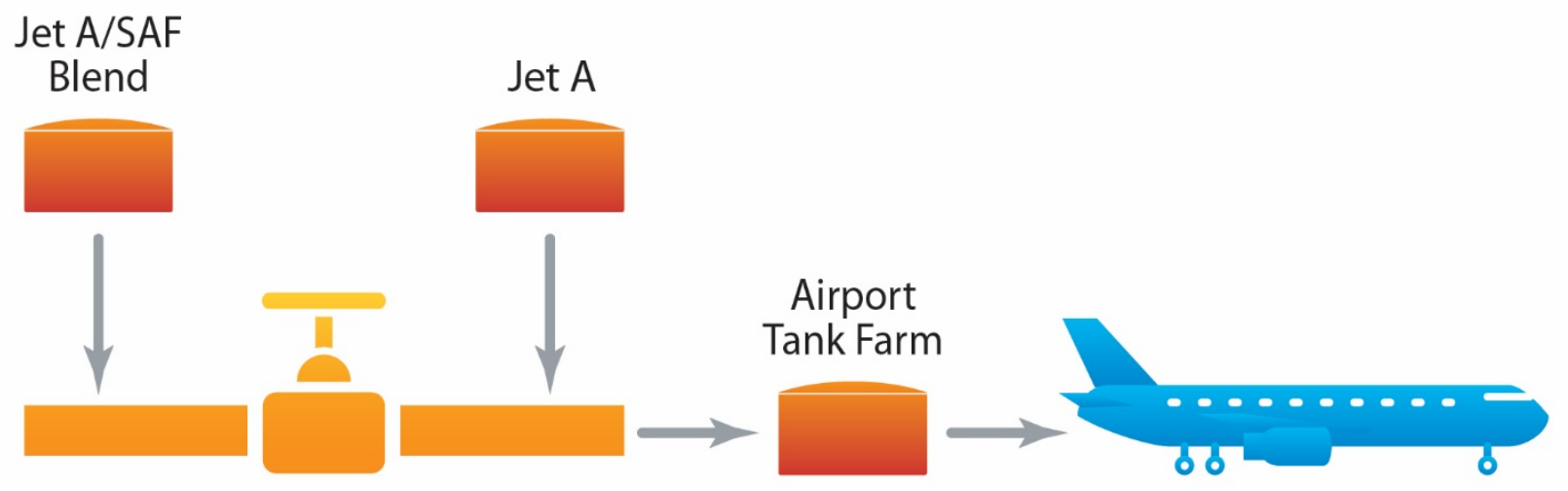

Figure ES-2. Option 2 for blending Jet A and SAF at a terminal

Several other blending scenarios are less likely, including blending fuels into the airport pipeline, blending at an airport or refinery, or establishing a new site upstream of the airport. Although it is possible to store Jet A and SAF in separate tanks and inject them both into the airport pipeline, this would result in the first instance of establishing SAF as ASTM 1655 at an airport. Airports are not set up for blending, which would require a significant investment in equipment and software. Blending at an airport may impact fuel tank farm insurance and the need for additional laboratory testing to generate COA paperwork. Due to the carefully controlled quality of jet fuel, it is ideal to establish quality and certification upstream from an airport. Refineries are extremely unlikely to accept fuel produced by a third party. Refineries do not have offloading equipment to accept third-party-produced fuel into their tanks. Also, introduction of SAF into the Jet A refinery storage tank would require recertification of the fuel. Refineries are designed for shortterm storage and sized to accommodate refinery production capacity, resulting in minimal excess capacity to store additional fuel. Although it is possible to establish a greenfield or brownfield site nearby the airport for blending, this would be more costly than blending at an existing terminal. 


\section{Table of Contents}

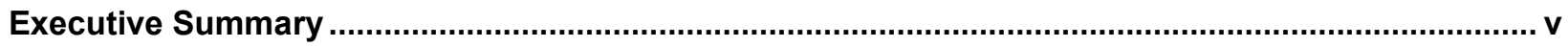

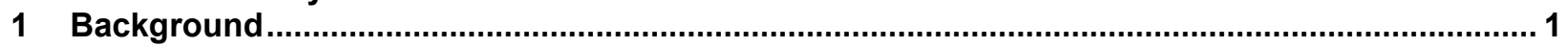

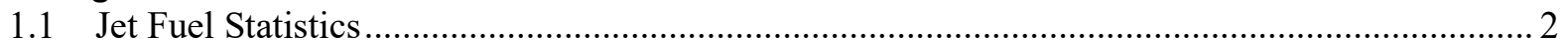

1.2 Sustainable Aviation Fuel Production....................................................................... 3

1.3 Jet Fuel Quality Standards, Certification, and FAA's Role .................................................5

1.3.1 Jet Fuel ASTM Standards and United Kingdom Ministry of Defense Standards ...........5

1.3.2 Certification of Quality ............................................................................6

1.3.3 Federal Aviation Administration Certification of Aircraft and Engines ....................... 8

2 Fuel Logistics.................................................................................................................... 8

2.1 Airport Infrastructure and Fuel Management............................................................. 8

2.2 Airport Infrastructure Data and Statistics.................................................................... 8

2.3 Jet $A$ and SAF Delivery Methods and Considerations .......................................................

2.4 SAF Blending Location Options .............................................................................. 10

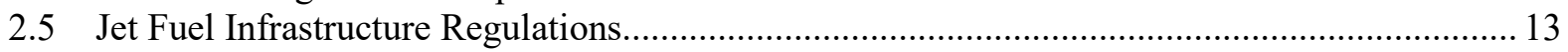

2.5.1 Aboveground Storage Tank Regulations .......................................................... 14

2.5.2 Airport Fuel Hydrant Systems and Field-Constructed Tanks .................................. 15

2.5.3 Jet Fuel Truck Transport .......................................................................... 16

2.5.4 State-Specific Regulatory Structures and Issues in Emerging Markets ...................... 16

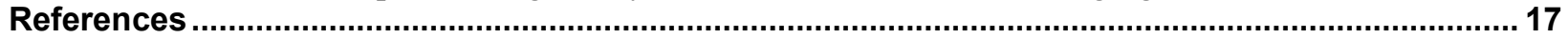

Appendix A Petroleum Administration for Defense Districts.................................................... 19

Appendix B ASTM D1655 and D7566 Summary ................................................................... 20 


\section{List of Figures}

Figure ES-1. Option 1 for blending Jet A and SAF at a terminal .........................................................vi

Figure ES-2. Option 2 for blending Jet A and SAF at a terminal ............................................................ vii

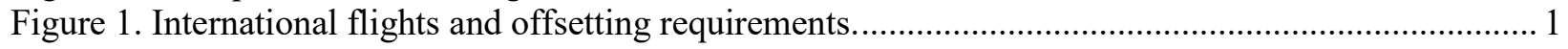

Figure 2. U.S. jet fuel consumption and enplanements.................................................................. 2

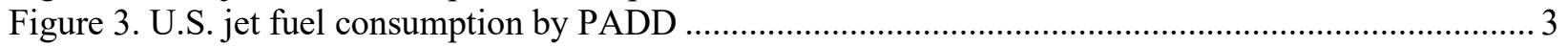

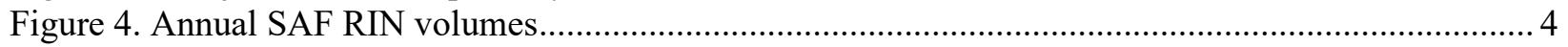

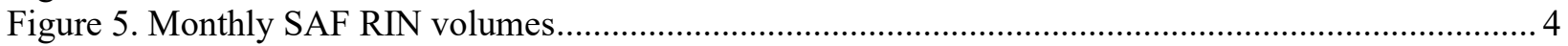

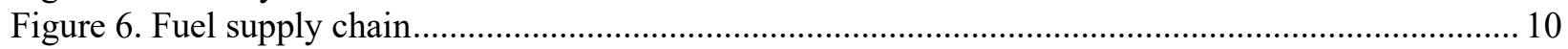

Figure 7. Option 1 Jet A and SAF blending at a terminal................................................................ 11

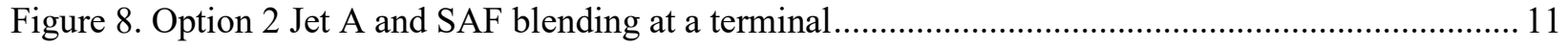

Figure A-1. Petroleum Administration for Defense Districts (PADDs) ................................................. 19 


\section{Background}

Airplane manufacturers increase the fuel economy by approximately $20 \%$ with each new generation of aircraft; however, that and other increases in efficiency are not sufficient to meet international agreements and individual industry company environmental and sustainability goals. In order to extend the reduction of emissions benefits and meet these goals, there has been significant interest in sustainable aviation fuel (SAF). The aviation industry defines SAF as a sustainable fuel made from a feedstock other than fossil fuels. ${ }^{4}$

In 2016, the International Civil Aviation Organization (ICAO), a branch of the United Nations, adopted the Carbon Offsetting and Reduction Scheme for International Aviation (CORSIA) to cap net $\mathrm{CO}_{2}$ aviation emissions at 2020 levels through 2035. Industry have also set aspirational goals of reducing $\mathrm{CO}_{2}$ emissions by $50 \%$ compared to 2005 levels by 2050 . Compliance began in 2019 with a requirement by airlines with annual emissions exceeding 10,000 tonnes to record fuel usage using one of five approved tracking methods. These data will be used to calculate $\mathrm{CO}_{2}$ emissions. Offsetting requirements, which can be met through a variety of project activities, began in 2021 for flights between voluntary countries and full implementation will begin in 2027 (Figure 1). There are also potential economic benefits and motivations for fuel producers who are subject to the federal Renewable Fuel Standard (RFS) and California's Low Carbon Fuel Standard (LCFS).

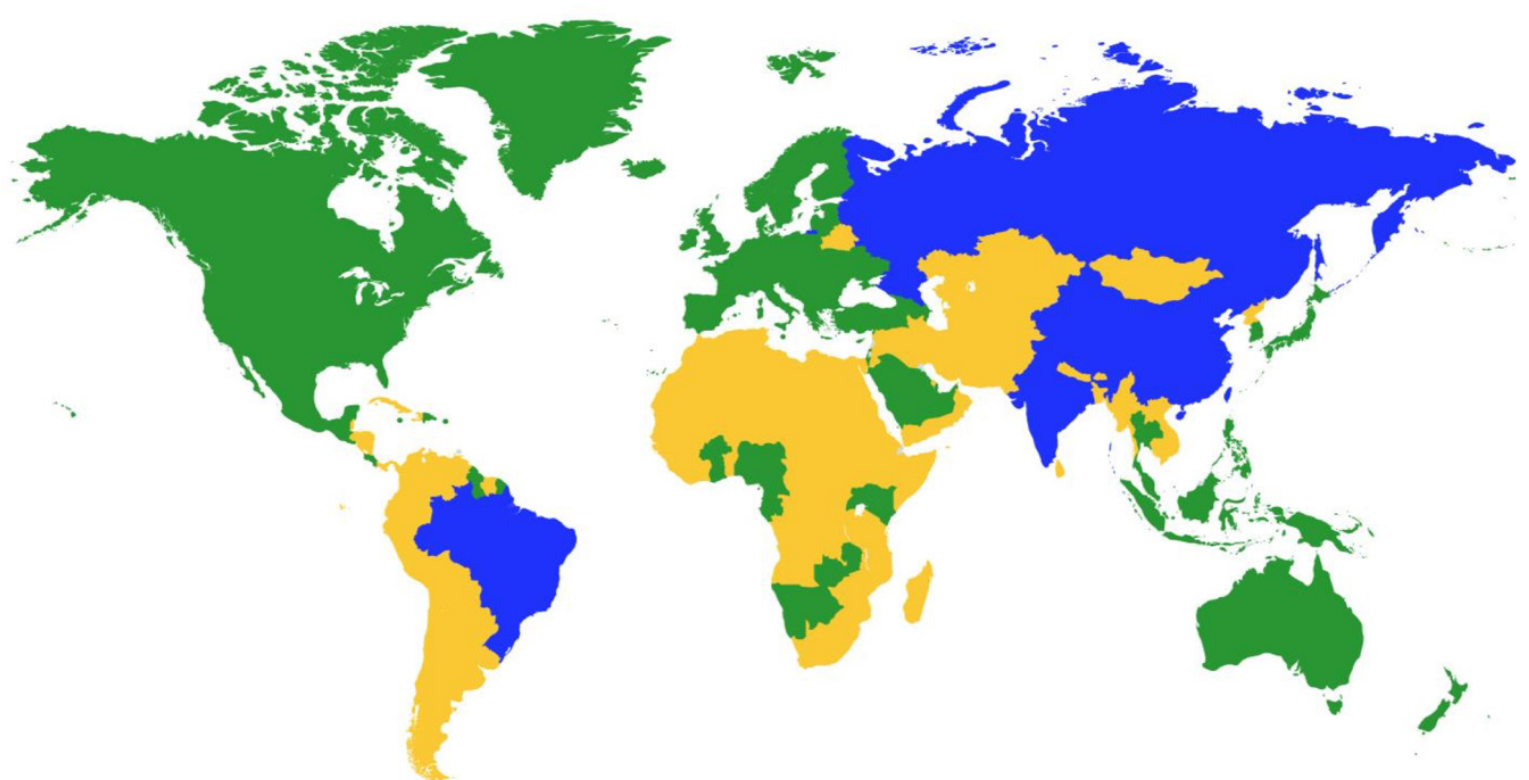

Figure 1. International flights and offsetting requirements.

Source: IATA 2020b. Note: International flights between voluntary (green) countries began in 2021 and expand to flights to/from blue countries in 2027. International flights to and from yellow countries are exempt.

\footnotetext{
${ }^{4}$ SAF is sometimes referred to as "biojet" and the U.S. Environmental Protection Agency (EPA) uses the term "renewable jet fuel."
} 


\subsection{Jet Fuel Statistics}

U.S. jet fuel consumption was nearly 27 billion gallons in 2019 (EIA 2020a) and has slowly increased over the past 5 years (Figure 2). In 2019, the United States accounted for $24 \%$ of the 98-billion-gallon global jet fuel consumption (EIA 2020a). The U.S. Energy Information Administration (EIA) tracks fuel data by five Petroleum Administration for Defense Districts (PADDs) (Appendix A). Figure 3 shows consumption by PADD; the highest jet fuel consumption occurs in PADDs 1 and $5 .^{5}$

The Federal Aviation Administration (FAA) reports that enplanements (the number of passengers boarding an aircraft) have grown from 696 million in 2009 to 937 million in 2019 (FAA 2020). ${ }^{6}$ Between 2018 and 2019, enplanements grew by $4 \%$ and fuel use by $2 \%$. The FAA projects growth of $1.9 \%$ and $3.9 \%$ for domestic and international enplanements, respectively, between 2019 and 2039 (FAA 2019). The United States represented 21\% of the 4.2 billion global enplanements in 2018 (IATA 2020a; FAA 2019).

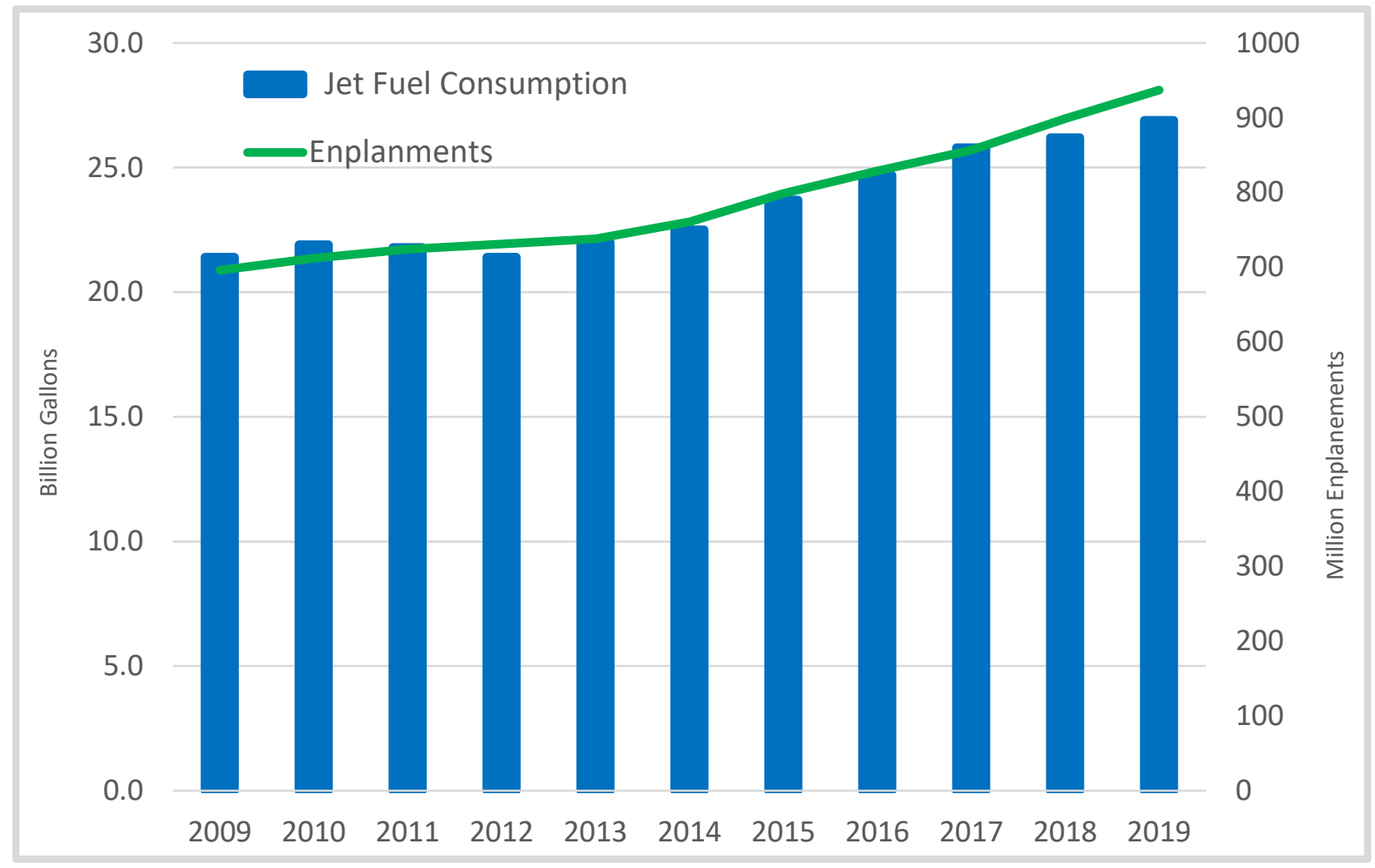

Figure 2. U.S. jet fuel consumption and enplanements

Sources: EIA 2020a; FAA 2020

\footnotetext{
${ }^{5}$ PADD 1: CT, DC, DE, FL, GA, MA, MD, ME, NC, NH, NJ, NY, PA, RI, SC, VA, VT, WV. PADD 2: IA, IL, IN, KS, KY, MI, MN, MO, NE, ND, OH, OK, SD, TN, WI. PADD 3: AL, AR, LA, MS, NM, TX. PADD 4: CO, ID, MT, UT, WY. PADD 5: AK, AZ, CA, HI, NV, OR, WA.

${ }^{6}$ Enplanements included in this section are for primary airports, defined as commercial airports with 10,000 or more passengers boarding each year.
} 


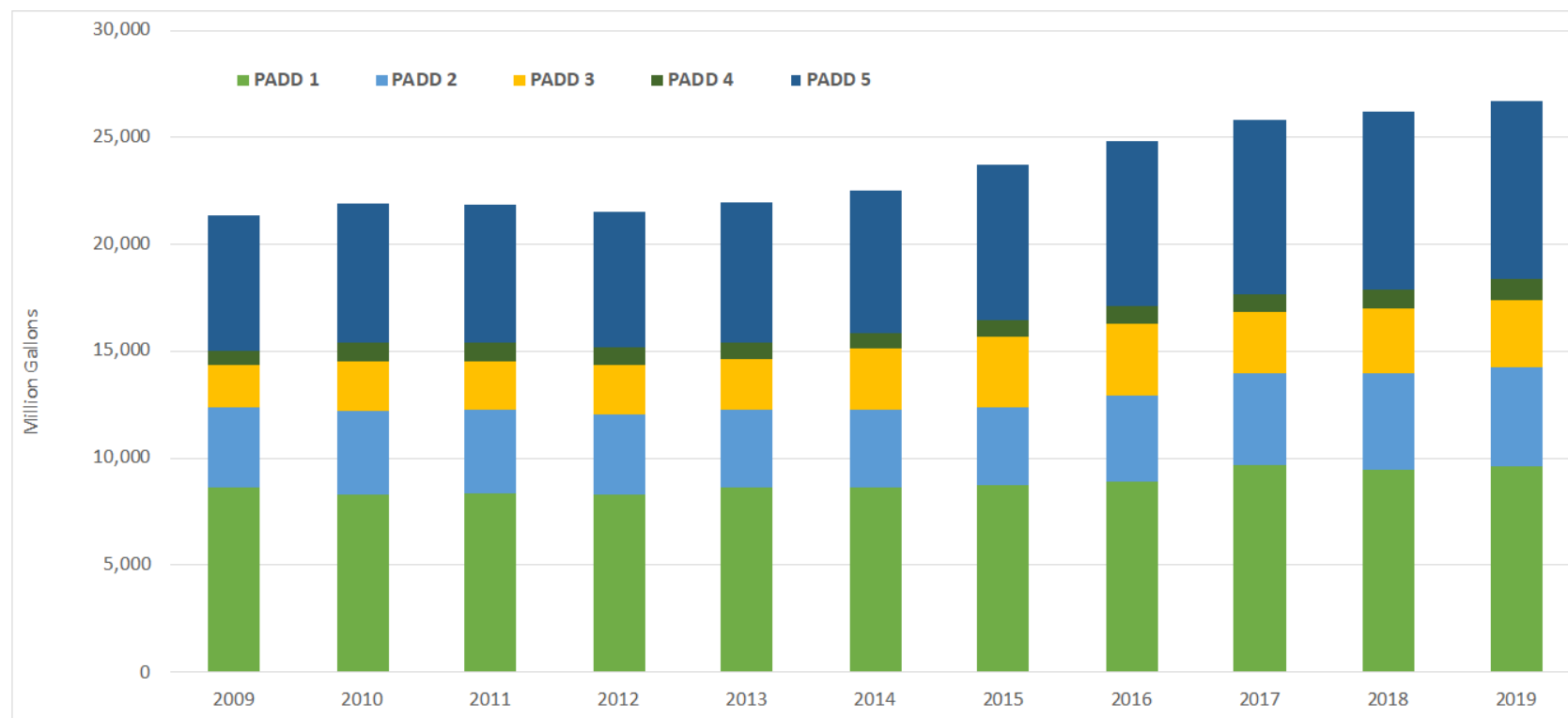

Figure 3. U.S. jet fuel consumption by PADD

Source: EIA 2020b

\subsection{Sustainable Aviation Fuel Production}

SAF production is in its early stages, with two known commercial producers. World Energy began SAF production in 2016 at their Paramount, California, facility and initially entered into a supply agreement with United Airlines, which later expanded to KLM for delivery to Los Angeles International Airport. International producer Neste began delivering SAF imported from their Rotterdam facility to San Francisco International Airport via pipeline from a terminal in July 2020. Both World Energy and Neste are expanding production capacity. There are also multiple plants under construction. Fulcrum Bioenergy's plant near Reno, Nevada, plans to convert 175,000 tons of municipal solid waste into a renewable synthetic crude, which will be transported by truck to a northern California refinery for processing into transportation fuels, including SAF (Fulcrum BioEnergy 2020). Red Rock Biofuels plans to convert 136,000 tons of wood waste into 15 million gallons of SAF and renewable diesel (Red Rock Biofuels 2020). Both Gevo and LanzaTech have developed technology to convert alcohol to SAF and have plans to build commercial plants. There are likely multiple other domestic and foreign entities developing technology to increase SAF production.

Actual production volumes of SAF are not reported; however, Renewable Identification Numbers (RINs), the compliance system for the RFS, provide an approximation of the market volume of SAF. Figure 4 shows fairly consistent RIN volumes between 2016 and 2018 and increases in 2019 through $2020 .^{7}$ At over 4.5 million gallons, SAF represents a tiny fraction of the U.S. jet fuel consumption of 26 billion gallons in 2019 (EPA 2020b; EIA 2020a). 2020 RIN generation suggests a significant increase in production, with large variability by month (Figure 5). The generation of RINs fluctuates throughout, a year which may indicate the availability of

\footnotetext{
${ }^{7}$ RIN data was not reported for February and May in 2020.
} 
feedstocks as well market dynamics, as some production plants can produce SAF and/or renewable diesel.

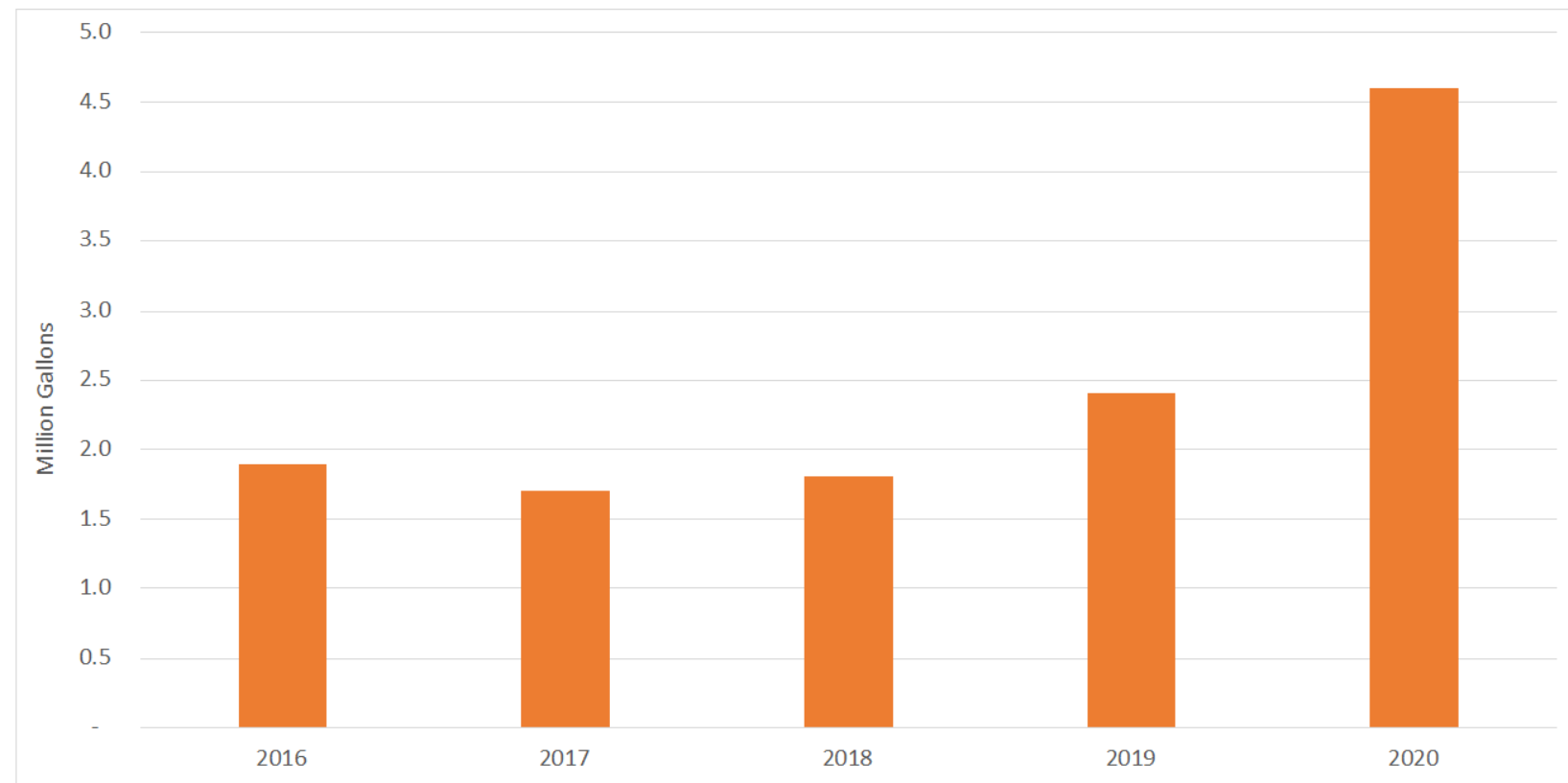

Figure 4. Annual SAF RIN volumes

Source: EPA 2020b.

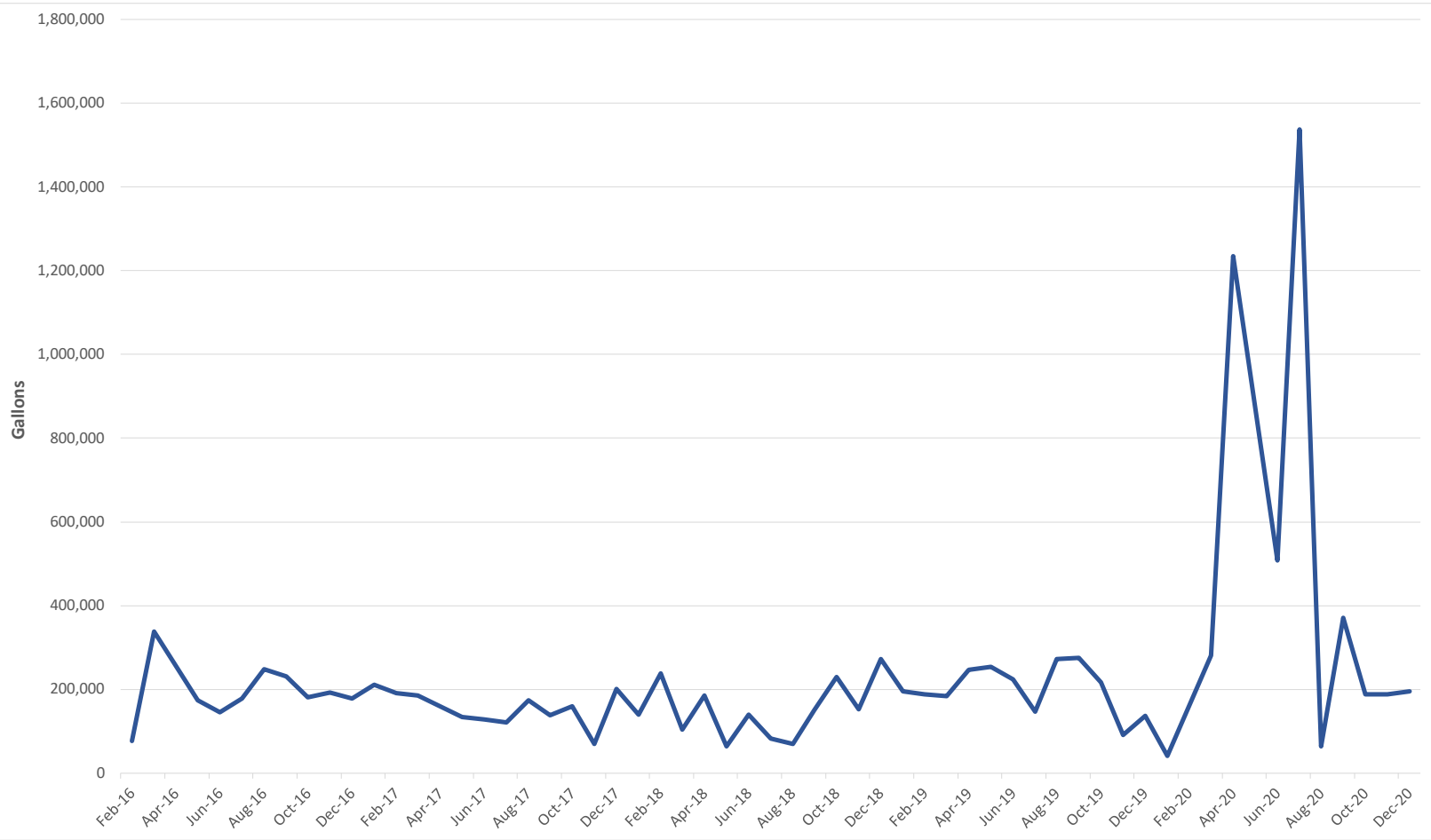

Figure 5. Monthly SAF RIN volumes

Source: EPA 2020b 


\subsection{Jet Fuel Quality Standards, Certification, and FAA's Role}

Jet fuel quality is carefully controlled through multiple harmonious standards adopted throughout the world. The approval for SAF and technology pathways is rigorous to ensure the quality and safety of the fuel. The FAA funded a report that provides detailed information on jet fuel quality and associated test methods, quality control throughout the supply chain, considerations on the introduction of SAF, and data collection (Miller et al. 2014).

\subsubsection{Jet Fuel ASTM Standards and United Kingdom Ministry of Defense Standards}

ASTM International is a voluntary consensus standards organization composed of aviation industry experts including airplane and engine manufacturers, fuel system equipment manufacturers, fuel producers, suppliers, users, and other interested parties. Industry experts meet regularly to create, maintain, and continuously update fuel quality specifications and test methods.

Jet fuel must meet ASTM D1655 Standard Specification for Aviation Turbine Fuels. ${ }^{8}$ Jet A is the fuel type used in the United States and Jet A-1 in the rest of the world. The fuels are nearly identical with the primary difference in the freezing point: Jet $\mathrm{A}$ at $-40^{\circ} \mathrm{C}$ and Jet $\mathrm{A}-1$ at $-47^{\circ} \mathrm{C}$. Appendix B summarizes ASTM D1655 fuel property requirements.

In 2009, ASTM D7566 Standard Specification for Aviation Turbine Fuel Containing Synthesized Hydrocarbons was amended to allow Fischer-Tropsch (FT) fuels, which can be made from biomass. ${ }^{9}$ ASTM D7566 fuel, when blended with Jet A in percentages outlined in D7566, also meets D1655 requirements and can be considered a D1655-complaint aviation fuel. Approved SAF production technology pathways are available in the specification annex. The pathway, as determined by critical properties, provides the uppermost limit that SAF may be blended with Jet A. Currently, there are seven synthetic paraffinic kerosene (SPK) and synthetic kerosene with aromatics (SKA) fuel categories approved by ASTM:

- Hydrogenated esters and fatty acids (HEFA) fuels (HEFA-SPK), 50\% maximum blend

- $\quad$ FT fuels (FT-SPK), 50\% maximum blend

- FT fuels with aromatics (FT-SKA), 50\% maximum blend

- Synthetic iso-paraffin (SIP) from fermented hydroprocessed sugar, formerly known as direct-sugar-to-hydrocarbon fuels (SIP-SPK), 10\% maximum blend

- Alcohol-to-jet (ATJ-SPK) fuels produced from isobutanol and ethanol, 50\% maximum blend

- Catalytic hydrothermolysis jet $(\mathrm{CHJ})$ produced from esters and fatty acids at a $50 \%$ maximum blend concentration

\footnotetext{
${ }^{8}$ Standards are continuously updated. Check the ASTM website for the latest version. https://www.astm.org/Standards/D1655.htm

${ }_{9}$ ASTM standards are continuously updated. Check the ASTM website for the latest version. https://www.astm.org/Standards/D7566.htm
} 
- HEFA with hydrocarbons (HC-HEFA) produced from esters and fatty acids at a 10\% maximum blend concentration.

Once a batch of SAF is tested to demonstrate compliance with D7566, it is blended with conventional Jet A and retested to show compliance with Table 1 of ASTM D7566. The blended fuel then meets the requirements of D1655.

The United Kingdom Ministry of Defence maintains another commonly used jet fuel quality standard, Defense Standard 91-091 “Turbine Fuel, Kerosene Type, Jet A-1” (Def Stan 91-091). The standard is nearly identical to ASTM D1655 with minimal differences for test limits for acidity level and naphthalene content. Around the world, the strictest elements of ASTM D1655 and Def Stan 91-091 are used per the checklist developed by the Aviation Fuel Quality Requirements for Jointly Operated Systems. Def Stan 91-091 includes a fuel traceability requirement for semi-synthetic jet fuel such as SAF.

\subsubsection{Certification of Quality}

Several entities including the Energy Institute, the Joint Inspection Group, the American Petroleum Institute, and SAE International develop best practices to safeguard fuel quality through the supply chain. ICAO, in collaboration with the International Air Transport Association (IATA), Airports Council International (ACI), and Airlines for America summarizes the best practices in the Manual on Civil Aviation Jet Fuel Supply (ICAO 2012). This document covers the entire supply chain including production, distribution, airport storage/hydrant systems, and delivery to aircraft. The document describes roles and responsibilities, required documentation, lab sampling test methods, and requirements.

Jet fuel and SAF travel by multiple modes of transportation including pipeline (neat SAF not permitted), truck, barge, and rail (uncommon for Jet A). Multiple fuel documents follow jet fuel to its end user. If the tested fuel falls outside any ASTM limits at the refinery or along the supply chain, the batch must be segregated from other fuel and retested to determine if the fuel can be used. A Refinery Certificate of Quality (RCQ) and Certificate of Analysis (COA) are documents used for quality control in contracts between buyers and sellers.

- An RCQ is generated at a refinery for each batch of jet fuel produced. The RCQ serves as a traceability document and includes batch number, refinery name, date, documentation that the tested fuel meets ASTM D1655 (Jet A), and type and volumes of additives. ${ }^{10}$

- A COA is generated by a certified and accredited third-party laboratory downstream from production at each transition point. COA documentation includes batch number, refinery name, date, documentation that the tested fuel meets ASTM D1655 or D7655, and related annex tables. $^{11}$

\footnotetext{
${ }^{10}$ RCQ and COA are similar documents. The RCQ may include additional information such as type and quantity of additives, and potentially any percent of non-hydroprocessed, mildly hydroprocessed, or severe hydroprocessed. The refiner typically generates the RCQ but is allowed to use an independent laboratory to generate an RCQ; the refiner is ultimately responsible for the laboratory results.

${ }^{11}$ A COA typically does not include additive information.
} 
- A COA typically includes results from Airlines for America's (A4A's) ATA Specification 103: Standard for Jet Fuel Quality Control at Airports. ${ }^{12}$

- The Metron Aviation study recommends generation of similar documents for neat and blended SAF (Miller et al. 2014). ${ }^{13}$

- ASTM D7566 Annex 4 recommends a format for quality documentation, and this could serve as the SAF equivalent of an RCQ (Miller et al. 2014). In addition to including the same information as an RCQ, it is recommended to also include the feedstock(s) and production pathway.

- At the point of blending for SAF and Jet A, a COA should be generated with original batch information for both SAF and Jet A, as well as SAF feedstock and production pathway.

- A Recertification Test Certificate (RTC) is generated in instances where there is risk of fuel contamination such as after jet fuel travels through a multiproduct pipeline or ocean vessel or in other instances where this is a risk of contamination. Its documentation is similar to RCQ, though not as many fuel parameters are tested. The testing makes sure specification limits are met and that there are no significant changes noted for each property in the test certificate.

SAF is blended with Jet A at the percentage determined by the end user or up to the allowable maximum percentage based on technology pathway. At this time, a COA with a new batch number is generated based on testing that demonstrates the fuel is compliant with ASTM D7566 Tables 1 and 2 and once confirmed, the fuel is designated as ASTM D1655. Although not required by ASTM, it would be a best practice and allow traceability to include the original batch numbers for both SAF and Jet A.

Best practices and standards differ in how to determine batch number and necessary fuel testing when fuels are blended. American Petroleum Institute's Recommended Practice 1543:

Documentation, Monitoring and Laboratory Testing of Aviation Fuel During Shipment from Refinery to Airport states that if two batches of jet fuel are co-mingled at a storage facility, the batch identity is lost. The pipeline industry has addressed this by generating batch numbers for volumetric accounting, but this does not carry over the COA from the original batches that were co-mingled, and the fuel is tested against ATA 103, which does not require full conformity testing after co-mingling of batches (Miller et al. 2014). For blends of Jet A and SAF, it is likely in the best interest for the emerging fuel to conduct a full conformity test and generation of a batch number as recommended by API 1543. The Metron Aviation study recommends that ATA 103 be amended to better match tests in ASTM D7655 that are not included in ASTM D1655 to ensure more complete fuel quality testing. This would include adding lubricity, aromatic, and sulfur tests and expanding the distillation test to match ASTM D1655 (Miller et al. 2014).

\footnotetext{
${ }^{12}$ Airlines for America (A4A), formerly Air Transport Association (ATA), provides airlines with the ATA 103 standard, which requires the following eight tests: visual appearance in a white bucket, gravity, distillation (10\%, $50 \%, 90 \%$, final boiling point, residue, loss), flash point, freezing point, water separation, copper corrosion, and existent gum. If an airline incorporates ATA 103 into their maintenance/operating manuals, then the airline must adhere to it under FAA regulations.

13 The Metron Aviation study was funded by FAA for use by industry, and although the report makes recommendations, these are not official FAA policy (Miller et al. 2014).
} 


\subsubsection{Federal Aviation Administration Certification of Aircraft and Engines}

The FAA does not directly regulate fuel; however, airworthiness of aircraft and their engines are certified by an authority in the country where the equipment is manufactured. In the United States, the FAA under 14 Code of Federal Regulation Part 33 provides the requirements for certification of engines. The original equipment manufacturer (OEM) conducts testing observed by FAA and results in a type certificate that indicates the specification for jet fuel allowable by the OEM for use in that engine. Initially, some engines were tested with SAF, but as new production pathways are approved, engine testing is not necessarily required. The FAA also issues operating certificates to airlines, which include reviews of an airline's operating manual that dictates the fuel used. FAA's Continuous Lower Energy, Emissions, and Noise (CLEEN) Program provides a 50\% cost share with OEMs with an objective of developing and demonstrating alternative jet fuels and aircraft technologies. ${ }^{14}$

\section{Fuel Logistics}

\subsection{Airport Infrastructure and Fuel Management}

All commercial airports have on-site fuel storage — an area called the tank farm. A tank farm comprises multiple interconnected pieces of equipment designed to safely receive, store, and dispense fuel to aircraft. Although not an all-inclusive list, a tank farm consists of tanks; pipeline interconnection; equipment to control the flow of fuel and vapors; meters to measure the volume of fuels into the tank farm and out to aircraft; filters to remove contaminants; pumps to move fuel throughout the system; safety equipment to prevent, detect, and contain leaks throughout the system; offloading rack to fill fuel trucks; and hydrant systems - underground pipes and hydrants. Generally, airports own the tank farm and lease it to an airline fuel consortium for operation. Smaller airports may operate under a different scheme where either the airport operates the fuel system or hires a third party to do so. Fuel is delivered to airplanes via a fuel hydrant system (underground pipes to each gate) or by fuel truck.

The purpose of airline fuel consortiums, common at U.S. airports, is to pool resources and ensure quality and timely delivery of jet fuel to all airlines through shared infrastructure. The airline consortium model allows airlines to source fuel from multiple fuel producers. Airline fuel consortia do not buy or sell fuel but act as the operator of the fuel infrastructure. Airlines are responsible for purchasing fuel and ensuring quality. The consortium may directly operate the infrastructure system or contract out operations to a third party.

\subsection{Airport Infrastructure Data and Statistics}

Airports size their fuel infrastructure to accommodate their peak week of the year and allow for future growth. However, the growth in enplanements and jet fuel use has constrained fuel infrastructure at some airports and there are some instances where demand exceeds pipeline capacity. This is compensated for by truck deliveries or fuel tankering - where an aircraft flies with more fuel than required for its flight. Truck deliveries help but are not ideal as it requires deliveries to be handled by the airside service contractor along with security procedures for both the fuel truck driver and entry into the secure area of the tank farm. Trucking fuel costs more than delivery by pipeline and it takes at least 20 minutes to offload a typical truck capacity of

${ }^{14}$ https://www.faa.gov/about/office org/headquarters_offices/apl/research/aircraft_technology/cleen/ 
7,500 gallons, which is not a substantial amount of fuel considering the capacity of a Boeing 737 is 6,875 gallons (Baciu 2010).

\subsection{Jet A and SAF Delivery Methods and Considerations}

The method of moving fuels throughout the country depends on the location of production, fuel type, and volume. The modes of transport for fuels include barge/ship, pipeline, rail, and truck

(Figure 6). The same rail cars, barges, and trucks are used to move multiple types of fuels. Fuels are sequenced (batched) through a pipeline based on their fuel properties. If dissimilar fuels come into contact in a pipeline, the transmix interface is delivered to a separate tank for reprocessing.

Jet A is moved primarily by pipeline, whereas biofuels produced at stand-alone facilities are moved by rail (large volumes) or truck (small volumes). If SAF is co-processed with conventional Jet A at an existing refinery, an RCQ would be generated at the refinery and the fuel would flow through the supply chain in a business-as-usual model via pipeline directly to an airport or, more commonly, by pipeline to a terminal and then by pipeline to an airport. A nearterm example of this is the expectation that Fulcrum BioEnergy will produce an intermediary product, renewable synthetic crude, which will be delivered to a petroleum refinery for coprocessing with crude oil into SAF.

SAF produced at a domestic stand-alone facility would likely travel by rail or truck to a fuel terminal for blending with Jet A. Imported SAF would be delivered by ship to a terminal. Neat SAF cannot travel by pipeline without a change to regulations set by the Federal Energy Regulatory Commission. However, a blend of SAF and Jet A meeting relevant ASTM standards can travel by pipeline. As of late 2020, Neste (an international producer) is exporting SAF to the West Coast, where it is blended with Jet A at a terminal and delivered to San Francisco International Airport via pipeline. Another anticipated example is Red Rock Biofuels, who expects to transport SAF by truck or rail to a terminal in Northern California for blending with Jet A.

World Energy, the sole commercial U.S. SAF production plant, blends SAF and Jet A at their production facility. Jet A is delivered to the World Energy site by truck, the fuels are blended, and an RCQ is generated. The blended fuel is delivered to Los Angeles International Airport by truck. This unique delivery scenario is viable for this project due to the low volumes, availability of Jet A nearby, and the proximity to the airport. The initial small volumes of SAF production may result in some unique blending situations and blended fuel may be delivered to an airport by truck where possible. This report focuses on blending options for SAF at anticipated higher volumes. 


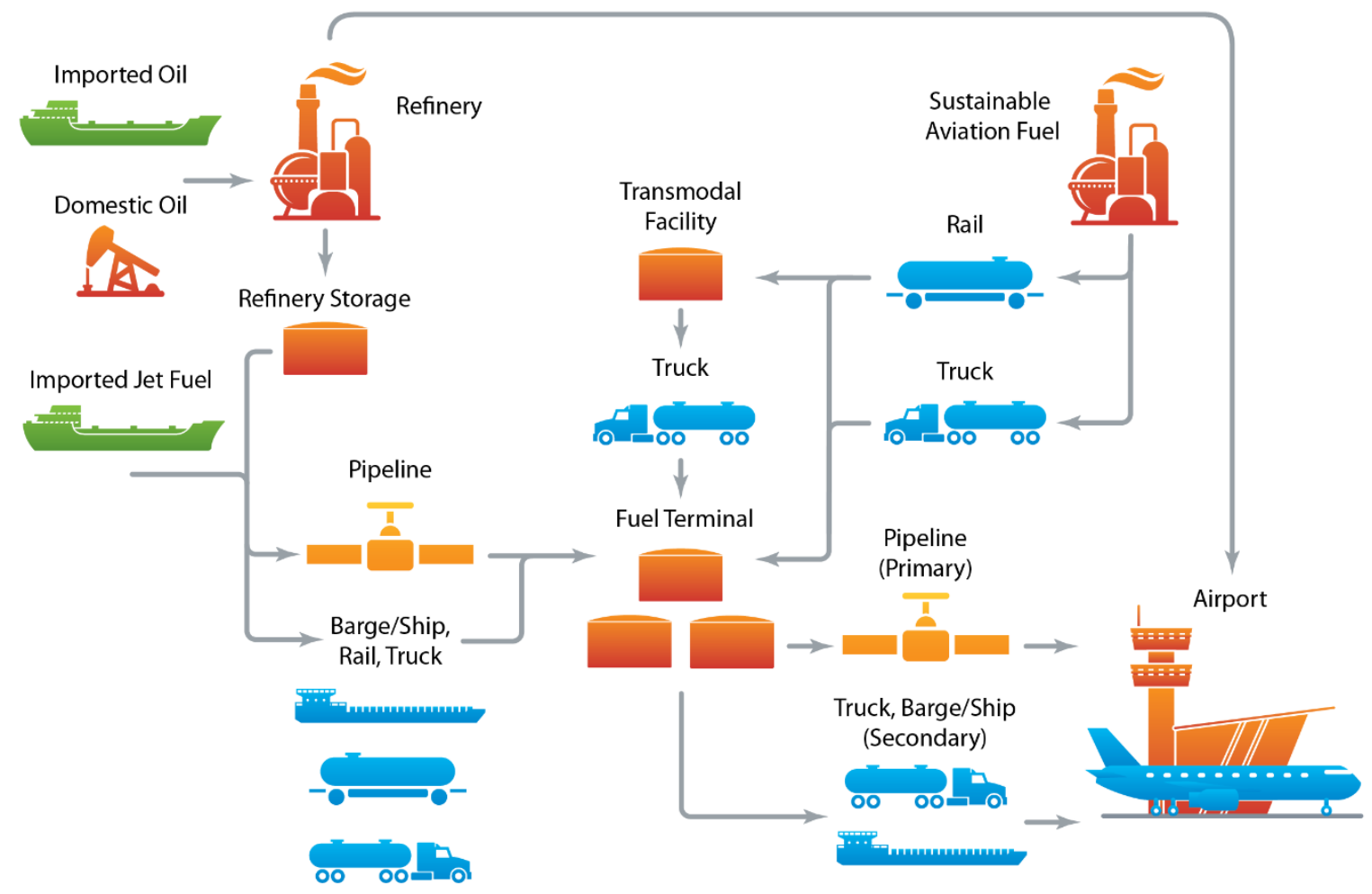

Figure 6. Fuel supply chain

\subsection{SAF Blending Location Options}

The requirements of quality control point toward blending SAF from a stand-alone facility with Jet $A$ at a terminal. Blending Option 1 and 2 could also be used to blend fuel for delivery by truck to airports not connected to pipelines. Terminals have the equipment and staff to safely blend fuels. There are at least 1,200 terminals across the United States storing petroleum products (Moriarty 2016).

- Option 1: Deliver SAF to terminal that serves an airport. Store SAF and Jet A in separate tanks and blend them into a third tank at the desired blend ratio (Figure 7). Sampling from the third tank would follow the steps outlined in Section 1.3 of this report to generate a COA demonstrating that the blended fuel meets ASTM D7655, and it if does, the blended fuel is designated as ASTM D1655 and is ready for shipment via pipeline to the airport.

- Option 2: Offload SAF delivered by rail or truck into a Jet A storage tank at a terminal (Figure 8). Sample and test fuel to generate a COA. This option may require the addition of mixing equipment on the tank to address potential differences in fuel gravities. Careful control of metering and fuel inventory will be necessary to identify the percent of SAF blended into Jet $\mathrm{A}$ and ensure it does not exceed allowable levels. 


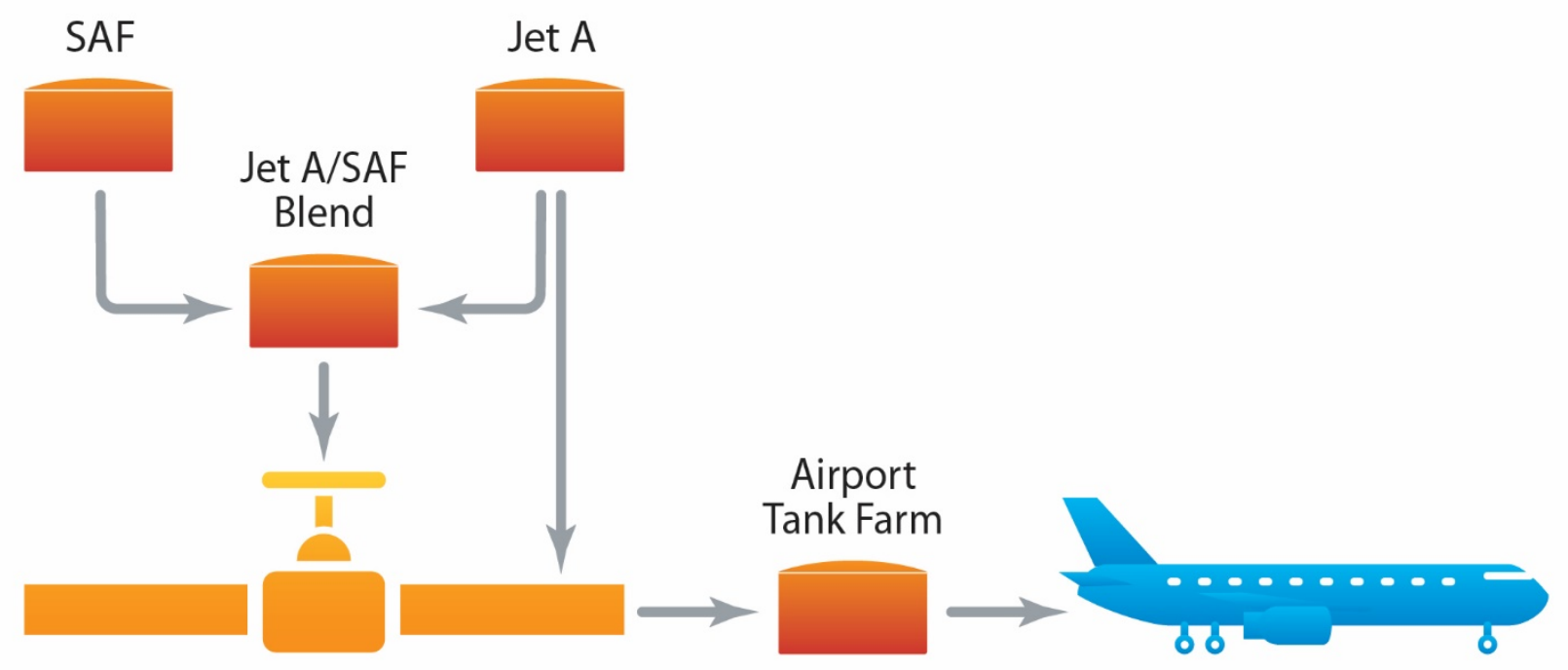

Figure 7. Option 1 Jet $A$ and SAF blending at a terminal

\section{Jet $A / S A F$}

Blend
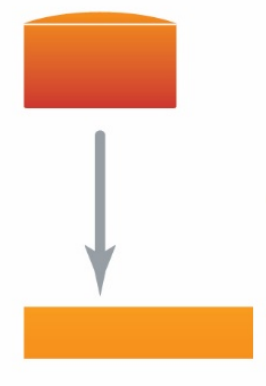

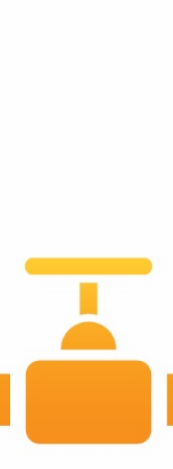

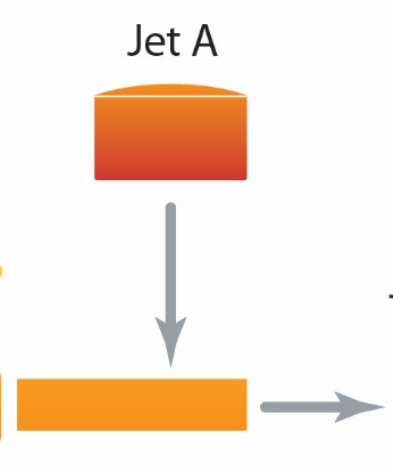

Airport Tank Farm

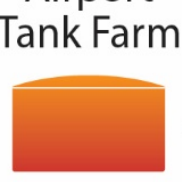

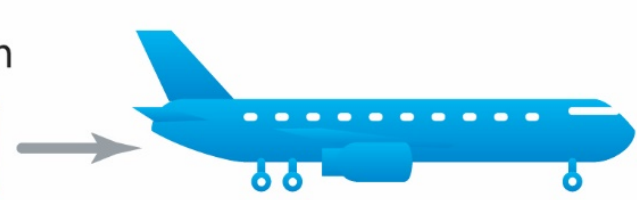

Figure 8. Option 2 Jet $A$ and SAF blending at a terminal

Other blending options are less desirable for myriad reasons:

- Terminal blending into pipeline: Although it is possible to store Jet A and SAF in separate tanks and inject them both into the airport pipeline, this would result in the first instance of establishing SAF as ASTM 1655 at an airport. In addition, although it may be expected that turbulent flow in the pipeline would mix the fuels, the fuel properties provided at the terminal must match the analysis done of fuel quality at the airport. There is some concern regarding differences in gravity between the two fuels.

- Blending at an airport: Delivering SAF to an airport for blending would be the first instance where the blend is established as ASTM 1655. It is preferable to mitigate any potential fuel quality issues upstream, where there is additional equipment and staff. Airports are not equipped with blending software, equipment, or the associated safety and leak detection and mitigation equipment. Additional laboratory testing beyond what is done at airports may be necessary to generate the COA paperwork. The airport refueling facility would likely require a different insurance policy to cover blending activities. 
Another consideration is the impact of SAF delivered by truck, which requires on-site staff and takes at least 20 minutes per truck to offload fuel. Truck traffic would increase at an airport proportional to the amount of SAF fuel delivered.

- Blending at a refinery: Refineries are extremely unlikely to accept fuel produced by a third party. Refineries do not have offloading equipment to accept a third-party-produced fuel into their tank. Also, introduction of SAF into the Jet A storage tank would require recertification of the fuel. Refinery storage is sized to accommodate refinery production capacity, resulting in minimal excess capacity to store an additional fuel.

- Greenfield/brownfield site: It is possible to establish a new site to store and blend Jet A and SAF. However, this would be significantly more expensive than utilizing equipment or even building new tank(s) at an existing terminal. Further, permitting for the facility and a pipeline to tie into the airport or the airport's existing pipeline would take a considerable amount of time.

Once the blended Jet A/SAF fuel is at the airport, even if the fuel is stored in a dedicated tank, it is unlikely that SAF would be delivered to a specific airline or flight. Large airports usually have a hydrant system and once fuel enters it, there is no differentiation in which flight the fuel is delivered to. Even for airports with truck delivery, fuel logistics would make it challenging to deliver fuel from a dedicated tank to a specific airline or flight.

\section{Terminal Considerations}

There are several types of companies that own terminals. The National Renewable Energy Laboratory classified these companies based on Oil Price Information Service (OPIS) data to gain insight into ownership (Moriarty 2016). Oil and refinery companies own the fuel though they also lease tanks and associated equipment to third-parties. Pipeline and terminal companies receive a fee for transporting and/or storing fuels and lease out their tanks and associated infrastructure. Lease terms vary but are generally at least one year and more if capital improvements are necessary to accommodate a fuel and blending.

- Oil: Vertically integrated companies that explore and drill for oil and refine it. These companies may also own pipelines. As of 2016, Chevron accounts for more than half of the capacity in this category.

- Refinery: Companies that own refineries and terminals. These companies may also own pipelines. As of 2016, the top five companies account for $65 \%$ of both terminals and capacity and include Marathon Petroleum, Motiva (a joint venture between Shell Oil Company and Saudi Aramco), and Phillips 66.

- Pipeline: Companies that own pipelines and lease storage space to customers at their terminals. Buckeye Partners, Kinder Morgan, and Magellan account for over $70 \%$ of this category as of 2016.

- Terminal: Companies that own one or more terminals but do not own pipelines or refineries. Although there is not consolidation of ownership in this category, TransMontaigne is a leader with $\sim 50$ terminals as of 2016 .

Fuels at U.S. terminals are typically stored separately. For example, ethanol, blendstock for oxygenate blending (the main component of gasoline), and additives are stored in separate tanks and when a truck pulls into the offloading rack, the fuel components are pulled from all three tanks, measuring volume with meters to deliver the final fuel product into the truck for delivery 
to the end user. Biodiesel, diesel, and Jet A are all stored separately. Nearly all terminals are able to blend fuels, but there are exceptions. A notable example is the large-scale Linden, New Jersey, terminal, which stores and does not blend fuels for delivery to Newark, LaGuardia, and John F. Kennedy airports.

There is the possibility that tanks may be available at a terminal, but if not, an infrastructure investment may be necessary to add tanks and/or associated blending equipment and dedicated lines to accommodate SAF. EIA reported that bulk terminals were using 53\% of their jet fuel storage capacity as of March 2020 (EIA 2020d). This report does not indicate if tanks are available - only that not all capacity is in use. In the case of ethanol, terminal companies saw a long-term market for ethanol, and many reported converting one tank and adding a new tank to meet demand for $10 \%$ ethanol in gasoline. The most economical and least timely opportunity is to use existing tanks, if available, at a terminal. If new tanks are necessary, the build out process can take time and in some instances may require additional permitting or a revision to a terminal's U.S. Environmental Protection Agency (EPA) operating permit.

If an airport pipeline is connected to a terminal, the airport or airline fuel consortium may consider leasing tanks for the purpose of storing and blending SAF.

\subsection{Jet Fuel Infrastructure Regulations}

This section provides an overview of environmental laws and regulations applicable to fueling operations and structures at airports, analyzes what utilizing biofuels at airports means for the regulation of those operations and structures, and examines state-specific regulatory issues in California and New York. Although myriad laws and regulations apply to activities at airports, this section analyzes only environmental laws and regulations applicable to airport fuels and fuel structures in an airport's transition from traditional fuels to biofuels. Other types of laws that apply to airports and their activities include zoning and land use planning laws, noise ordinances, FAA regulations, and Occupational Safety and Health Administration regulations, among others.

Aboveground storage tank farms are typically regulated by the EPA under an operating permit. Airport tank farms are the rare exception to this regulation and are regulated by individual states. It is presumed that state regulations mirror those summarized herein.

A number of federal environmental laws including the Clean Air Act; Clean Water Act; Resource Conservation and Recovery Act; Comprehensive Environmental Response, Compensation, and Liability Act; Toxic Substances Control Act; and Safe Drinking Water Act regulate activities and structures at airports. ${ }^{15}$ The EPA oversees the administration of these laws through a system of cooperative federalism, in which state and tribal governments may apply for and receive primary oversight and enforcement responsibilities (EPA 2020a). When a state has an EPA-approved delegated program, regulatory approvals come from the state government and EPA retains federal oversight over the state's implementation of the federal laws and regulations. In some cases, states may add requirements to what is already required federally, but in no case

\footnotetext{
${ }^{15}$ The National Environmental Policy Act also may apply to activities conducted at airports. The Council on Environmental Quality oversees its implementation by federal agencies.
} 
may an EPA-approved state's program be less stringent than the federal standards. ${ }^{16}$ Although many environmental laws regulate activities and structures at airports, this section focuses on regulated activities implicated in an airport's transition from traditional fuels to biofuels and biofuel mixes.

Fuels are involved in a number of different types of structures at airports, including aboveground storage tanks (ASTs), field-constructed tanks (FCTs), airport fuel hydrant systems (AHSs), connected pipelines, and trucks transporting fuel to airports. Most of these structures have traditionally housed fossil fuels, but some airports and airlines have already begun to utilize SAF in their operations. SAF meets the same ASTM fuel quality standard as Jet A, and therefore compatibility issues are not expected.

\subsubsection{Aboveground Storage Tank Regulations}

ASTs are commonly used to store oils and chemicals and are a frequent source of environmental contamination. ${ }^{17}$ At airports, ASTs may be used as single tanks or in a larger group of tanks, often called a tank farm. Because ASTs and underground storage tanks (USTs) have caused widespread environmental contamination, certain technical standards are now used to protect against leaks. Particular types of ASTs are subject to both federal and state laws.

ASTs holding oils of any type may be subject to EPA's Spill Prevention, Control, and Countermeasure (SPCC) regulation, which aims to prevent discharges of oil into navigable waters. ${ }^{18}$ This rule applies to facilities with a total AST oil capacity of more than 1,320 gallons in containers of 55 gallons or more and to facilities that have a total buried storage capacity over 42,000 gallons (Defense Logistics Agency 2020). The SPCC regulations regulate ASTs under the term "bulk storage container," which is defined as "any container used to store oil.".19 Subparts B and C of the SPCC regulation require that all bulk storage containers have a secondary means of containment for the entire capacity of the largest single container and sufficient freeboard to contain precipitation. ${ }^{20}$ This regulation also contains design, engineering, integrity testing, monitoring, corrective action, training, staffing, and recordkeeping requirements for bulk storage containers. ${ }^{21}$

Permits issued through the National Pollutant Discharge Elimination System in 40 C.F.R. § 122 also contain requirements for tank management (Defense Logistics Agency 2020). States that have such an EPA-approved program typically require that the facility inspect tanks at least monthly for leaks. ${ }^{22}$ Regulatory agencies also usually require that facilities prevent wash water

\footnotetext{
${ }^{16}$ See, for example, Norman A. Dupont's chapter "Federal Preemption of State and Local Environmental Laws" in James R. May's Principles of Constitutional Environmental Law (2011): "Both the CAA in section 166 and the Clean Water Act in section 510 expressly anticipate that states or localities could set standards that are 'no less stringent' than federally mandated minimums. These provisions seem to permit further state and local regulation as long as the federal minimum standard (or floor) is not breached."

${ }^{17}$ USTs are a leading source of groundwater contamination (EPA 2020d).

${ }^{18}$ See 40 C.F.R. $\S 112$.

1940 C.F.R. $\$ 112.2$.

${ }^{20}$ See 40 C.F.R. $\S 112.8(c)(2), 112.12(c)(2)$.

${ }^{21}$ Ibid.

${ }^{22}$ Ibid.
} 
from tank cleanings from reaching the ground or storm drain systems. ${ }^{23}$ EPA's Resource Conservation and Recovery Act regulations for hazardous waste in 40 C.F.R. $\S 264$, Subpart J and 40 C.F.R. $\S 265$, Subpart J also contain requirements for the design, construction, testing, and inspection of ASTs used to store hazardous wastes.

Several fire code regulations are also relevant to ASTs. The International Code Council's International Fire Code is typically adopted by state fire marshals. ${ }^{24}$ The code contains design and operational standards for types of facilities, processes, and materials. ${ }^{25}$ Relevant to airport fueling operations, the International Fire Code addresses combustible and flammable liquids storage, aviation facilities, motor fuel dispensing facilities and repair garages, hazardous materials, flammable gases and solids, liquefied petroleum gases, and oxidizers. ${ }^{26}$ The National Fire Protection Association's Fire Code 1 includes design standards and operational requirements for ASTs and Flammable and Combustible Liquids Code 30 contains design and operational standards for fixed and portable tanks and piping systems. ${ }^{27}$

The U.S. Coast Guard's regulations on transferring oil and hazardous materials in bulk, located in 33 C.F.R. $\S 154$, applies to facilities transferring oil or hazardous materials from vessels with a total capacity of 250 barrels or more. This regulation contains operational requirements as well as procedures for spills, leaks, cleaning, labeling, and reporting. It also requires that owners and operators keep descriptions, instructions, and locations for certain types of facilities and systems. $^{28}$

The Occupational Safety and Health Administration's regulations about the management of flammable and combustible liquids in 29 C.F.R. $\S 1910.106$ contain requirements for tank farm drainage, diked areas, dispensing areas of service stations, and the disposal and storage of crankcase drainings and other flammable and combustible wastes. There are also hazardous communication rules in 29 C.F.R. $§ 1910.1200$, which requires that workers know about the hazards of the chemicals they use and that tanks and containers be properly labeled.

ASTs may need to meet additional state and local design, environmental, fire safety, and worker safety requirements. It is important for owners and operators of ASTs to consult the relevant state and local authority's regulations to determine what standards are required during the lifetime of an AST.

\subsubsection{Airport Fuel Hydrant Systems and Field-Constructed Tanks}

AHSs distribute fuel to aircrafts and operate under high pressure with large diameter piping that end in hydrants, which are also known as fill stands. ${ }^{29}$ AHSs often have more than one tank and include ASTs, USTs, FCTs, underground piping that is directly connected, and other connected tanks holding fuel such as settling tanks and pressure relief tanks. ${ }^{30}$ AHSs do not include tanks

${ }^{23}$ Ibid.

${ }^{24}$ Ibid.

${ }^{25}$ Ibid.

${ }^{26}$ Ibid.

${ }^{27}$ Ibid.

${ }^{28}$ Ibid.

${ }^{29}$ Ibid.

${ }^{30}$ Ibid. 
not storing fuel, such as additive tanks, tanks that are not directly connected, and any piping connected to these other types of tanks. ${ }^{31}$ AHSs may be regulated as a UST system if $10 \%$ or more of its total capacity is underground. ${ }^{32}$ Tanks that are not regulated under 40 C.F.R. $\S 280$ may need to follow other regulatory requirements, such as those under EPA's SPCC regulation. FCTs are tanks constructed in the field and are not built like conventional UST systems. ${ }^{\text {Error! }}$ Bookmark not defined. Instead, they are built on site, are not prefabricated, and are typically bulk underground storage tanks. Although UST regulations did not originally apply to AHSs or FCTs, EPA added requirements under 40 C.F.R. $\S 280$, Subpart K. ${ }^{33}$

EPA has different requirements for FCTs and AHSs installed before and after October 13, 2015. There are additional requirements for USTs installed or replaced after April 11, 2016, and associated with FCTs, AHSs, or underground piping associated with FCTs that are less than 50,000 gallons. EPA also created additional requirements for FCTs and AHSs installed after October 13, 2018.

\subsubsection{Jet Fuel Truck Transport}

Trucks that transport jet fuels may also be regulated through both federal and state environmental rules. In the bulk transport of fuels, a major concern is that an accident could occur in which the vessel is damaged and a large amount of fuel is spilled (EPA 2011). Using trucks to transport fuels also creates air quality concerns from the combustion associated with driving the vehicles, particularly in nonattainment areas under the Clean Air Act. Air emissions may also result from "evaporative, spillage, and permeation emissions and emissions" (EPA 2011).

The Clean Air Act's emission standards for mobile sources include cars, trucks, airplanes, vessels, and off-road engines and vehicles (EPA 2020c). EPA administers these standards on a national level, including emission, fuel, and fleet requirements (EPA 2020c). In all of the most seriously polluted ozone and carbon monoxide nonattainment areas, centrally fueled fleets of 10 or more passenger cars and light-duty trucks must purchase at least $70 \%$ clean-fuel vehicles when they add new vehicles to existing fleets, and heavy-duty fleets are required to purchase at least $50 \%$ clean-fuel vehicles annually.

\subsubsection{State-Specific Regulatory Structures and Issues in Emerging Markets}

Regulatory schemes of states and localities vary considerably. Therefore, it is important for owners and operators of regulated activities to research state and local regulatory provisions before proceeding.

\footnotetext{
${ }^{31}$ Ibid.

${ }^{32}$ In calculating the capacity of the AHS to determine whether it is regulated as a UST system $(\geq 10 \%$ capacity underground), aboveground piping is excluded in the calculation, but underground piping is included. USTs that do not store fuel, such as emergency generator and additive USTs, are also not included in the $\geq 10 \%$ calculation or the definition of an AHS system.

${ }^{33}$ Ibid.
} 


\section{References}

Air Transport Action Group (ATAG). 2019. "Facts \& Figures." Accessed September 2019. https://www.atag.org/facts-figures.html.

Baciu, Julia. 2010. “1998-2010 Boeing 737-800.” TopSpeed, March 1, 2010, accessed September 2019. https://www.topspeed.com/aviation/aviation-reviews/boeing/1998-2010-boeing-737-800ar85475.html.

Defense Logistics Agency. 2020. "Chapter 4 Aboveground Storage Tanks and Containers." Accessed November 2020.

https://www.dla.mil/Portals/104/Documents/Energy/Publications/Environmental\%20Guide\%20f or\%20Fuel\%20Facilities/Chapter4_AbovegroundStorageTanksandContainers_Mar2019.pdf?ver $=2019-04-17-084152-207$

Federal Aviation Administration (FAA). 2020. "Passenger Boarding (Enplanement) and AllCargo Data for U.S. Airports.” Accessed October 2020.

https://www.faa.gov/airports/planning capacity/passenger allcargo stats/passenger/.

- 2019. FAA Aerospace Forecast Fiscal Years 2019-2039. Washington, D.C.: FAA. TC19-0002. https://www.faa.gov/data_research/aviation/aerospace forecasts/media/FY201939_FAA_Aerospace_Forecast.pdf.

Fulcrum BioEnergy. 2020. "Facilities." Accessed October 2020. https://fulcrumbioenergy.com/facilities/.

International Air Transit Association (IATA). 2020a. "Carbon offsetting for international aviation." June 2020. https://www.iata.org/contentassets/fb745460050c48089597a3eflb9fe7a8/ paper-offsetting-for-aviation.pdf

—. 2020b. "Fact Sheet: CORSIA.” July 2020.

https://www.iata.org/contentassets/fb745460050c48089597a3ef1b9fe7a8/corsia-fact-sheet.pdf.

International Civil Aviation Organization (ICAO). 2012. Manual on Civil Aviation Jet Fuel Supply. Montreal, Canada: ICAO. Doc 9977 AN/489.

Miller, Bruno, Donovan Johnson, Terry Thompson, Frank L. Rosenberg, Judith Driver, Gerard P. Biscardi, Madalina K. Mohtadi, and Nabil J. Mohtadi. 2014. R\&D Control Study: Plan for Future Jet Fuel Distribution Quality Control and Description of Fuel Properties Catalog. Dulles, VA: Metron Aviation, Inc. DOT/FAA/AEE/2014-11. https://www.faa.gov/about/office_org/headquarters_offices/apl/research/alternative_fuels/media/ Metron_Fuel_Quality_Final.pdf.

Moriarty, Kristi. 2016. High Octane Fuel: Terminal Backgrounder. NREL/TP-5400-65760. Golden, CO: National Renewable Energy Laboratory. https://www.nrel.gov/docs/fy16osti/65760.pdf 
Red Rock Biofuels. 2020. “Lakeview Site.” Accessed October 2020.

https://www.redrockbio.com/lakeview-site.html.

U.S. Energy Information Administration (EIA). 2020a. "Jet fuel consumption, United States, Annual, (thousand barrels per day).” Accessed October 2020.

https://www.eia.gov/opendata/qb.php?category=2135044.

- 2020b."Product Supplied.” Accessed October 2020.

https://www.eia.gov/dnav/pet/pet_cons_psup_de_nus_mbbl_a.htm.

-. 2020c. Working and Net Available Shell Storage Capacity as of March 31, 2020.

Washington, D.C.: EIA. https://www.eia.gov/petroleum/storagecapacity/storagecapacity.pdf.

U.S. Environmental Protection Agency (EPA). 2020a. "Cooperative Federalism at EPA." https://www.epa.gov/home/cooperative-federalism-epa.

_. 2020b. "Public Data for the Renewable Fuel Standard." Accessed October 2020. https://www.epa.gov/fuels-registration-reporting-and-compliance-help/public-data-renewablefuel-standard.

—. 2020c. "Regulatory Information by Topic: Air." https://www.epa.gov/regulatoryinformation-topic/regulatory-information-topic-air.

- 2020d. "Revising Underground Storage Tank Regulation - Revisions to Existing Requirements and New Requirements for Secondary Containment and Operator Training; Final Rule." https://www.epa.gov/ust/revising-underground-storage-tank-regulation-revisions-existingrequirements-and-new. 


\section{Appendix A Petroleum Administration for Defense Districts}

\section{Petroleum Administration for Defense Districts}

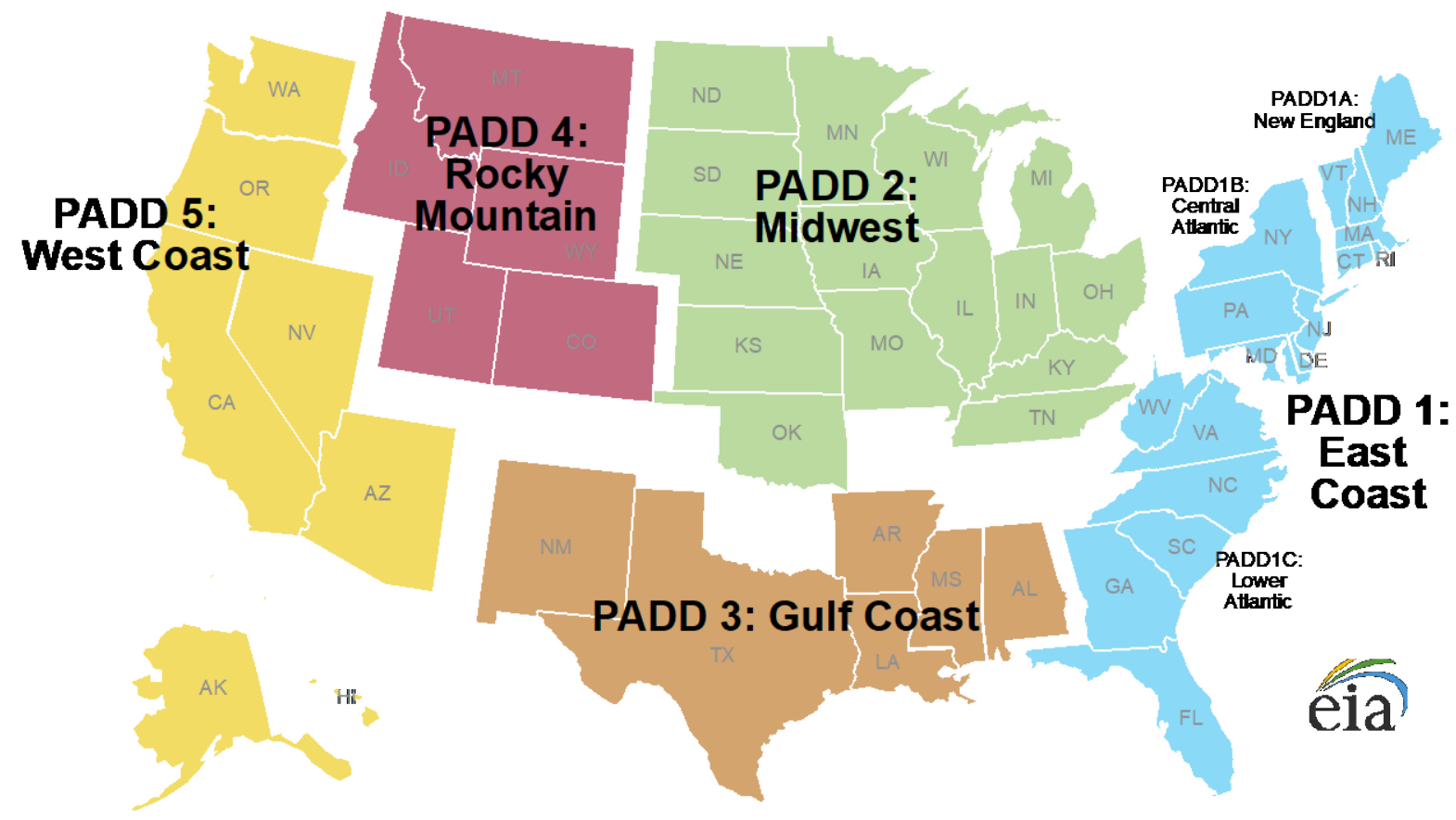

Figure A-1. Petroleum Administration for Defense Districts (PADDs)

Source: Energy Information Agency, https://www.eia.gov/petroleum/marketing/monthly/pdf/paddmap.pdf 


\section{Appendix B ASTM D1655 and D7566 Summary}

\section{REQUIREMENT}

SPECIFICATION

ASTM TEST METHOD

D1655

D7566

\section{COMPOSITION}

Acidity, total mg KOH/g

1. Aromatics, vol \%

2. Aromatics, vol \%

Sulfur, mercaptan, $C$ mass $\%$

Sulfur, total mass $\%$

\section{VOLATILITY}

Distillation temp, ${ }^{\circ} \mathrm{C}$

T10 (10 \% recovered, temp)

T50 (50\% recovered, temp)

T90 (90\% recovered, temp)

$\mathrm{T} 50-\mathrm{T} 10$

$\mathrm{T} 90-\mathrm{T} 10$

Final boiling point, temp

Distillation residue, \%

Distillation loss, \%

Flash point, ${ }^{\circ} \mathrm{C}$

$$
\max 0.10
$$

$\max 0.10$

D3242

$\max 25$

$\max 26.5$

$\max 0.003$

$\max 0.003$

D3227

$\max 0.30$

$\max 0.30$

D1266, D2622, D4294, D5453

$\max 25$
$\min 8$

D6379

$\min 8.4$

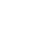


REQUIREMENT

\begin{tabular}{|c|c|c|c|}
\hline & D1655 & D7566* & \\
\hline \multicolumn{4}{|l|}{ DENSITY } \\
\hline Density at $15^{\circ} \mathrm{C}, \mathrm{kg} / \mathrm{m} 3$ & 775 to 840 & 775 to 840 & D1298 or D4052 \\
\hline \multicolumn{4}{|l|}{ FLUIDITY } \\
\hline \multirow[t]{2}{*}{ Freezing point, ${ }^{\circ} \mathrm{C} \max$} & -40 Jet $A$ & -40 Jet $A$ & $\begin{array}{l}\text { D5972, D7153, } \\
\text { D7154, D2386** }\end{array}$ \\
\hline & -47 Jet $A-1$ & -47 Jet $A-1$ & \\
\hline Viscosity $-20^{\circ} \mathrm{C}, \mathrm{mm} 2 / \mathrm{sl}$ & $\max 8.0$ & $\max 8.0$ & D445 \\
\hline \multicolumn{4}{|l|}{ COMBUSTION } \\
\hline Net heat of combustion $\mathrm{MJ} / \mathrm{kg}$ & $\min 42.8$ & $\min 42.8$ & $\begin{array}{l}\text { D4529, D3338, or } \\
\text { D4809 }\end{array}$ \\
\hline \multicolumn{4}{|l|}{ One of the following requirements shall be met: } \\
\hline (1) Smoke point, mm, or & $\min 25$ & $\min 25$ & D1322 \\
\hline (2) Smoke point, $\mathrm{mm}$, and & $\min 18$ & $\min 18$ & D1322 \\
\hline Naphtalenes, vol, \% & $\max 3.0$ & $\max 3.0$ & D1840 \\
\hline \multicolumn{4}{|l|}{ CORROSION } \\
\hline Copper strip, 2 h at $100^{\circ} \mathrm{C}$ & $\max$ No. 1 & $\max$ No. 1 & D130 \\
\hline \multicolumn{4}{|l|}{ THERMAL STABILITY } \\
\hline Filter pressure drop, mm Hg & $\max 25$ & $\max 25$ & D3241 \\
\hline $\begin{array}{l}\text { Tube deposits No Peacock or Abnormal Color } \\
\text { Deposits }\end{array}$ & less than 3 & less than 3 & \\
\hline
\end{tabular}




\begin{tabular}{|c|c|c|c|}
\hline \multirow[t]{2}{*}{ REQUIREMENT } & \multicolumn{2}{|c|}{ SPECIFICATION } & \multirow[t]{2}{*}{ ASTM TEST MET } \\
\hline & D1655 & D7566* & \\
\hline \multicolumn{4}{|l|}{ CONTAMINANTS } \\
\hline Existent gum, mg/100 mL & $\max 7$ & $\max 7$ & D381**, IP 540 \\
\hline Microseparometer, Rating & & & D3948 \\
\hline Without electrical conductivity additive & $\min 85$ & $\min 85$ & \\
\hline With electrical conductivity additive & $\min 70$ & $\min 70$ & \\
\hline $\begin{array}{l}\text { Electrical conductivity } \mathrm{pS} / \mathrm{m} \text { (with } \\
\text { electrical conductivity additive) }\end{array}$ & $\max 600$ & $\max 600$ & D2624 \\
\hline Lubricity mm & & 0.85 & D5001 \\
\hline
\end{tabular}

